\title{
Streptomyces griseoruber Y1B, a Novel Streptomyces for 1-Hydroxyphenazine Production
}

\author{
Junyuan Hui \\ State Key Laboratory of Microbial Metabolism, School of Life Sciences and Biotechnology, \\ Shanghai Jiao Tong University, 800 Dongchuan Road, Shanghai, China \\ Tel: 86-021-3420-7047Ｅ-mail: yuzecheng@sjtu.edu.cn
}

Wei Wang (Corresponding author)

State Key Laboratory of Microbial Metabolism, School of Life Sciences and Biotechnology, Shanghai Jiao Tong University, 800 Dongchuan Road, Shanghai, China

Tel: 86-021-3420-7047Ｅ-mail: weiwang100@sjtu.edu.cn

\section{Hongbo $\mathrm{Hu}$}

State Key Laboratory of Microbial Metabolism, School of Life Sciences and Biotechnology, Shanghai Jiao Tong University, 800 Dongchuan Road, Shanghai, China Tel: 86-021-3420-7047 E-mail: hbhu@sjtu.edu.cn

\section{Huasong Peng}

State Key Laboratory of Microbial Metabolism, School of Life Sciences and Biotechnology, Shanghai Jiao Tong University, 800 Dongchuan Road, Shanghai, China Tel: 86-021-3420-7047Ｅ-mail: hspeng@sjtu.edu.cn

\section{Xuehong Zhang}

State Key Laboratory of Microbial Metabolism, School of Life Sciences and Biotechnology, Shanghai Jiao Tong University, 800 Dongchuan Road, Shanghai, China Tel: 86-021-3420-6715 E-mail: xuehzhang@sjtu.edu.cn

Received: April 11, 2014 Accepted: May 13, 2014 Published: May 20, 2014

Doi: 10.5296/jab.v2i2.5430 URL: http://dx.doi.org/10.5296/jab.v2i2.5430 


\begin{abstract}
Strain Y1B was isolated from a soil sample collected from Wuxi in Jiangsu Province, China. The strain was identified as Streptomyces griseoruber based on phenotypic characteristics and 16S rRNA gene sequence analysis. $p h z E$ and $p h z F$ gene fragments were amplified by PCR from S. griseoruber Y1B, and showed $70-80 \%$ similarity to those of phenazine-producing Pseudomonas and Streptomyces species, indicating that this strain contained phenazine biosynthetic genes and had the potential to produce phenazine compounds. A crude extract, obtained from S. griseoruber Y1B fermentation broth by organic solvent extraction and evaporation under reduced pressure, showed significant antifungal activity against Rhizoctonia solani, Pythiumultimum, and Fusarium oxysporum, and had a broad spectrum of antifungal activity. A phenazine compound, 1-hydroxyphenazine, and a shikimic acid-derived metabolite, benzoic acid, were separated and purified from the crude extract by preparative high performance liquid chromatography. The effects of addition of intermediate metabolites on 1-hydroxyphenazine production implied that the phenazine biosynthesis pathway in $S$. griseoruber Y1B might branch off from the shikimate pathway, using phenazine-1-carboxylic acid as the phenazine precursor. Furthermore, this is the first demonstration that $S$. griseoruber can produce phenazine compounds. Therefore, as a novel Streptomyces strain, S. griseoruber Y1B might have potential applications for biocontrol in agricultural production.
\end{abstract}

Keywords: Streptomyces griseoruber Y1B, 1-Hydroxyphenazine, Antifungal activity, Phenazine biosynthetic gene, Isolation 


\section{Introduction}

Natural phenazines are a kind of broad spectrum antibiotic. They are nitrogenous heterocyclic compounds with various substituent groups at different sites of the core phenazine ring, such as phenazine-1-carboxylic acid (PCA), 1-hydroxyphenazine (1-OH-PHZ), pyocyanin and endophenazines, which show a wide range of biological activities (Ligon et al., 2000; Krastel et al., 2002; Laursen \& Nielsen, 2004; Mentel et al., 2009). Natural phenazine products are bioactive secondary metabolites that are mainly produced by Pseudomonas and Streptomyces species from soil and marine environments, which provide abundant resources to discover more phenazine-producing strains (Saleh et al., 2012).

The biosynthetic mechanism of natural phenazine compounds has been well studied, and the phenazine biosynthetic gene cluster has been characterized. For most phenazine-producing strains, phenazine biosynthesis begins with the shikimate pathway. The gene products of $p h z C, p h z E$ and $p h z D$ catalyze the biosynthesis of 3-deoxy-D-arabino-heptulosonic acid 7-phosphate (DAHP), 2-amino-2-deoxyisochorismic acid (ADIC), and trans-2, 3-dihydro-3-hydroxyanthranilic acid (DHHA), respectively. $p h z F$ may be responsible for the isomerization of DHHA (McDonald et al., 2001; Mentel et al., 2009; Pierson III \& Pierson, 2010). Consequently, these genes can be used as markers to detect phenazine-producing strains.

In this study, a novel phenazine-producing strain, Y1B, was isolated from soil and was identified as $S$. griseoruber. Here we describe the identification, taxonomy, phenazine biosynthetic genes, and antifungal activity of $S$. griseoruber Y1B, as well as the purification and chemical structures of its bioactive compounds. We also propose a phenazine biosynthesis pathway for this species. This is the first demonstration that $S$. griseoruber can produce phenazine compounds.

\section{Materials and Methods}

\subsection{Collection of Soil Samples}

Ten soil samples were collected from the rice fields of Wuxi in Jiangsu Province, China. The fresh soil was sampled from a depth of $10 \mathrm{~cm}$ from the soil surface. Each of the soil samples was placed in a sterilized plastic bag and stored at $4{ }^{\circ} \mathrm{C}$ for further study.

\subsection{Isolation of Strain Y1B}

The soil samples were carefully crushed and dried in a $60{ }^{\circ} \mathrm{C}$ incubator for $30 \mathrm{~min}$. Five grams of the soil samples were added to $45 \mathrm{ml}$ of sterilized water and were shaken for $30 \mathrm{~min}$, followed by 10 -fold serial dilutions of the soil suspension. Two hundred microliters of the $10^{-2}, 10^{-3}, 10^{-4}$, and $10^{-5}$ dilutions of each soil sample were spread in Gause's No. 1 synthetic medium (soluble starch $20 \mathrm{~g} \mathrm{l}^{-1}, \mathrm{KNO}_{3} 1 \mathrm{~g} \mathrm{l}^{-1}, \mathrm{~K}_{2} \mathrm{HPO}_{4} 0.5 \mathrm{~g} \mathrm{l}^{-1}, \mathrm{MgSO}_{4} \cdot 7 \mathrm{H}_{2} \mathrm{O} 0.5 \mathrm{~g} \mathrm{l}^{-1}$, $\mathrm{FeSO}_{4} \cdot 7 \mathrm{H}_{2} \mathrm{O} 0.01 \mathrm{~g} \mathrm{l}^{-1}$, $\mathrm{NaCl} 0.5 \mathrm{~g} \mathrm{l}^{-1}$, agar $20 \mathrm{~g} \mathrm{l}^{-1}$, $\mathrm{pH} \mathrm{7.2-7.4)} \mathrm{containing} 0.1 \%(\mathrm{w} / \mathrm{v})$ $\mathrm{K}_{2} \mathrm{Cr}_{2} \mathrm{O}_{7}$ and incubated at $28{ }^{\circ} \mathrm{C}$ for 7-10 days. Single colonies picked from the primary medium were purified three times in SFM agar medium (soybean flour $20 \mathrm{~g} \mathrm{l}^{-1}$, mannitol $20 \mathrm{~g}$ $1^{-1}$, agar $20 \mathrm{~g}^{-1}, \mathrm{pH} 7.2-7.3$ ). 
$p h z E$ and $p h z F$ were selected as phenazine biosynthetic gene markers to screen novel phenazine-producing strains. Primers for each gene are listed in Table 1. PCR reaction was performed in the $50 \mu 1$ reaction system containing $100 \mathrm{ng}$ of DNA template, $2 \times$ GC Buffer II, $2.5 \mathrm{mM}$ dNTP Mixture, $20 \mu \mathrm{M}$ of each primer, $5 \mathrm{U} / \mu \mathrm{LA}$ Taq polymerase with the PCR Kit (TAKARA Biotech). PCR amplification conditions for $p h z E$ and $p h z F$ fragments were as follows: initial denaturation at $94{ }^{\circ} \mathrm{C}$ for $2 \mathrm{~min}$, followed by 36 cycles of $94{ }^{\circ} \mathrm{C}$ for $1 \mathrm{~min}$, $54.7^{\circ} \mathrm{C}(p h z E)$ and $57{ }^{\circ} \mathrm{C}(p h z F)$ for $1 \mathrm{~min}$, and $72{ }^{\circ} \mathrm{C}$ for $2 \mathrm{~min}$, and a final extension at $72{ }^{\circ} \mathrm{C}$ for $7 \mathrm{~min}$. PCR products were purified and sequenced by Sangon Biotech. Strain Y1B was isolated with positive PCR amplification results.

Table 1. Primers used in this study

\begin{tabular}{llll}
\hline Primer & Sequence & Function & Reference \\
\hline$p h z E-\mathrm{F}$ & $5^{\prime}$-GAAGGCGCCAACTTCGTYATCAA-3' & PCR and sequencing & (Schneemann \\
$p h z E-\mathrm{R}$ & 5'-GCCYTCGATGAAGTACTCGGTGTG-3' $^{\prime}$ of $p h z E$ & et al., 2011) \\
$p h z F-\mathrm{F}$ & 5'-ATCTTCACCCCGGTCAACG-3' $^{\prime}$ & PCR and sequencing & (Schneemann \\
$p h z F-\mathrm{R}$ & $5^{\prime}$-CCRTAGGCCGGTGAGAAC-3' & of $p h z F$ & et al., 2011) \\
$7 \mathrm{f}$ & $5^{\prime}$-CAGAGTTTGATCCTGGCT-3' & PCR and sequencing & (Brosius \\
$1450 \mathrm{r}$ & $5^{\prime}$-AGGAGGTGATCCAGCCGCA-3' & of the 16S rRNA gene & et al., 1978) \\
\hline
\end{tabular}

\subsection{Taxonomy of Strain Y1B}

Strain Y1B was cultured on SFM agar medium at $28{ }^{\circ} \mathrm{C}$ for 7 days, and colonies were collected for fatty acid analysis. The whole-cell fatty acids were saponified, methylated and extracted, and the composition of fatty acids was analyzed by comparing their retention times with Gas Chromatography (GC), according to the standard Sherlock Microbial Identification System (MIDI) (Eerola \& Lehtonen, 1988; Kroppenstedt et al., 1990).

Genomic DNA was extracted from strain Y1B using the EasyPure Genomic DNA Kit (TransGen Biotech). The 16S rRNA gene was amplified by PCR using the primers listed in Table 1. Based on the PCR reaction system of Par. 2.2, PCR conditions were as follows: initial denaturation at $94{ }^{\circ} \mathrm{C}$ for $5 \mathrm{~min}$, followed by 35 cycles of denaturation at $94{ }^{\circ} \mathrm{C}$ for $30 \mathrm{~s}$, annealing at $55{ }^{\circ} \mathrm{C}$ for $35 \mathrm{~s}$, extension at $72{ }^{\circ} \mathrm{C}$ for $1 \mathrm{~min}$, and a final extension at $72{ }^{\circ} \mathrm{C}$ for 8 min. 16S rRNA PCR products were purified and sequenced by Sangon Biotech.

\subsection{In Vitro Antifungal Activity Assay}

Four plant pathogens viz., Rhizoctonia solani, Pythiumultimum, Fusarium oxysporum, and Stevia rebaudiana Bertoni spot blight, were used as target pathogens to determine the antifungal activity of strain Y1B. Each of the plant pathogens was cultured on potato dextrose agar (PDA) medium (potato $200 \mathrm{~g} \mathrm{l}^{-1}$, glucose $20 \mathrm{~g} \mathrm{l}^{-1}$, agar $15 \mathrm{~g} \mathrm{l}^{-1}$ ) at $28{ }^{\circ} \mathrm{C}$ for 7 days (Shirzad et al., 2012). 
The crude extract of strain Y1B fermentation broth was used to test antifungal activity against the four plant pathogens. Strain Y1B was cultured in shake flasks in GYM medium (glucose $4 \mathrm{~g} \mathrm{l}^{-1}$, yeast extract $4 \mathrm{~g} \mathrm{l}^{-1}$, malt extract $10 \mathrm{~g} \mathrm{l}^{-1}, \mathrm{pH} \mathrm{7.2)} \mathrm{at} 28^{\circ} \mathrm{C}$ for 6 days on a rotary shaker $(180 \mathrm{rpm})$. Following fermentation, the supernatant was separated from the fermentation broth by centrifugation at $8225 \times g$ for $10 \mathrm{~min}$ (Centrifuge 5804R, Eppendorf). The culture supernatant was extracted three times with an equal volume of ethyl acetate. The organic phase was separated and evaporated under reduced pressure to obtain the crude extract.

Antifungal activity was tested by the mycelial growth rate method (Gorgolous \& Dekker, 1982). Briefly, the crude extract was dissolved in dimethylsulfoxide (DMSO), and the extract-DMSO solution was mixed with PDA medium to make test plates containing a crude extract concentration of $50 \mathrm{mg} \mathrm{l}^{-1}$. An equal volume of sterile water and DMSO was mixed with PDA medium to make a blank control plate and a solvent control plate, respectively. An 8-mm mycelial plug from a fresh plant pathogen culture was placed in the middle of a test plate, as well as on a blank control plate and a solvent control plate. Following incubation at $28{ }^{\circ} \mathrm{C}$ for 5 days, the diameter of the mycelial plug was measured to calculate relative inhibition rate using the following formula:

$$
\text { Relative inhibition rate }(\%)=\frac{\text { Diameter of solvent control }- \text { Diameter of sample test }}{\text { Diameter of blank control }- \text { Initial diameter }} \times 100 \%
$$

where the initial diameter of the mycelial plug is $8 \mathrm{~mm}$.

\subsection{Purification of the Active Compound}

Strain Y1B was cultivated in $25 \mathrm{~L}$ batches using GYM medium in shaker incubator. After cultivation for 6 days, the supernatant was separated by centrifugation and was extracted with ethyl acetate as Par. 2.4.

The crude extract of strain Y1B fermentation broth was purified by preparative High Performance Liquid Chromatography (HPLC, Agilent 1260) on a C18 reversed-phase column (Agilent Eclipse XDB-C18, $5 \mu \mathrm{m}, 4.6 \times 250 \mathrm{~mm}$ ), eluting with $\mathrm{CH}_{3} \mathrm{CN}-\mathrm{H}_{2} \mathrm{O}(50: 50, \mathrm{v} / \mathrm{v})$ as the mobile phase at a flow rate of $0.6 \mathrm{ml} \mathrm{min}^{-1}$. The purification yielded compound 1 and fraction $\mathrm{I}$ at retention times of 9.8 and $12.4 \mathrm{~min}$, respectively.

Fraction I was further purified by preparative HPLC (Agilent 1260) on the same C18 column, eluting with $\mathrm{CH}_{3} \mathrm{OH}-0.1 \% \mathrm{CH}_{3} \mathrm{COOH}$ aqueous solution $(55: 45, \mathrm{v} / \mathrm{v})$ as the mobile phase at a flow rate of $0.6 \mathrm{ml} \mathrm{min}^{-1}$. The purification yielded compound 2 at the retention time of 5.5 $\min$.

\subsection{Structure Determination of the Active Compound}

The electrospray ionization MS (ESI-MS) and UV absorption spectra of compound 1 were measured on an Agilent HPLC 1290-MS 6230 apparatus. The ESI-MS and ultra-performance liquid chromatography tandem MS (UPLC-MS-MS) spectra of compound 2 were measured on an ACQUITY UPLC \& Q-TOF MS Premier machine. ${ }^{1} \mathrm{H}$ NMR spectra were recorded on a Bruker Advance III $400 \mathrm{MHz}$ spectrometer. 
2.7Production of Phenazine with the Addition of Intermediate Metabolites

Based on the phenazine biosynthesis and shikimate pathways, PCA, L-phenylalanine and compound 2 were selected as intermediate metabolites, and were added on day 4 of fermentation in GYM at final concentrations of $0.02 \mathrm{mM}, 0.04 \mathrm{mM}, 0.06 \mathrm{mM}, 0.08 \mathrm{mM}$ and $0.1 \mathrm{mM}$. After 6 days of fermentation, the crude extract was dissolved in methanol for further analysis. Compound 1 was detected at $254 \mathrm{~nm}$ by preparative HPLC (Agilent 1260) on the same $\mathrm{C} 18$ column, eluting with $\mathrm{CH}_{3} \mathrm{CN}-\mathrm{H}_{2} \mathrm{O}(50: 50, \mathrm{v} / \mathrm{v})$ at a flow rate of $0.6 \mathrm{ml} \mathrm{min}$.

\subsection{Data Analysis}

The phylogenetic tree of strain Y1B and its relatives based on 16S rRNA gene sequence was constructed using MEGA software version 4.0 with the neighbor-joining method (Saitou \& Nei, 1987; Tamura et al., 2007).

\section{Results and Discussions}

\subsection{Identification of Strain Y1B}

The 16S rRNA gene sequence (1400 bp, GenBank accession no. KF991392) of strain Y1B was aligned with sequences from the GenBank database by BLAST analysis (Tatusova \& Madden, 1999). The results indicated that strain Y1B belonged to the genus Streptomyces, and that the 16S rRNA gene sequence of strain Y1B showed $100 \%$ similarity to that of $S$. griseoruber. A phylogenetic tree was constructed using the neighbor-joining method with different type strains of the genus Streptomyces (Figure 1). The tree also showed that strain Y1B was closely related to $S$. griseoruber, and shared a branch with $S$. griseoruber JCM 4642. Consequently, we designated the strain $S$. griseoruber Y1B.

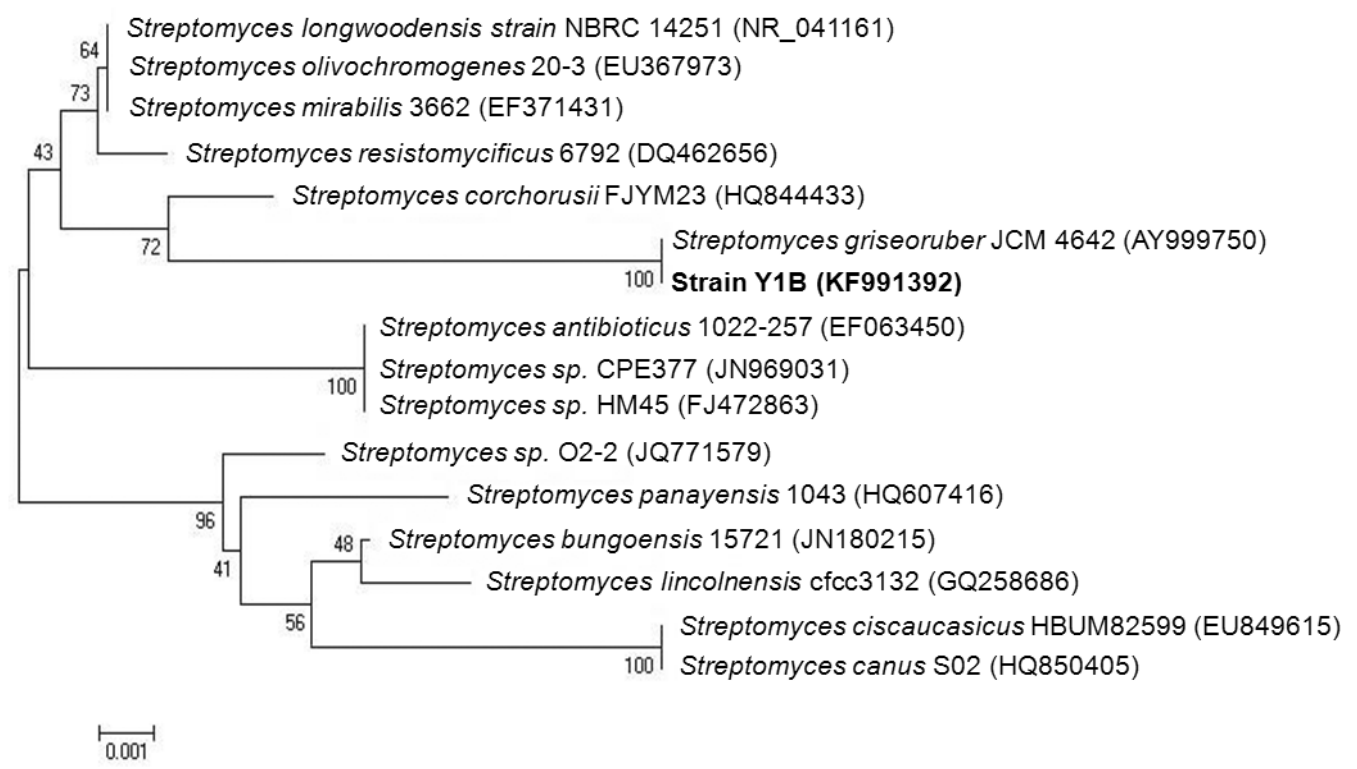

Figure 1. Phylogenetic tree of strain Y1B and its relatives based on 16S rRNA gene sequence analysis using the neighbor-joining method. The tree was constructed by MEGA software version 4.0. Bootstrap values are based on 1000 replicates. The scale bar represents 1 substitution per 1000 bases 


\subsection{Taxonomy of Strain Y1B}

S. griseoruber Y1B grew on SFM agar medium and formed grey colonies that were circular, smooth, and dry. As shown in Table 2, the cellular fatty acids of S. griseoruber Y1B mainly included anteiso-C15:0 (23.03\%), iso-C16:0 (16.04\%), anteiso-C17:0 (12.24\%), C16:0 $(10.96 \%)$, and iso-C15:0 (10.33\%). This is the first description of fatty acid analysis of Streptomyces griseoruber.

Table 2. Fatty acid profile of S. griseoruber Y1B

\begin{tabular}{ll}
\hline Fatty acids & Content $(\%)$ \\
\hline anteiso-C13:0 & 0.28 \\
iso-C14:0 & 2.45 \\
C14:0 & 0.73 \\
iso-C15:0 & 10.33 \\
anteiso-C15:0 & 23.03 \\
C15:1 B & 0.30 \\
C15:0 & 1.10 \\
iso-C16:1 H & 3.59 \\
iso-C16:0 & 16.04 \\
C16:1 cis 9 & 5.67 \\
C16:0 & 10.96 \\
C16:0 9 methyl & 2.21 \\
anteiso-C17:1 C & 3.45 \\
iso-C17:0 & 3.07 \\
anteiso-C17:0 & 12.24 \\
cyclo-C17:0 & 3.90 \\
C17:0 & 0.25 \\
C18:3 cis 6,12,14 & 0.38 \\
\hline
\end{tabular}

\subsection{Identification of Phenazine Biosynthetic Gene Fragments from Strain Y1B}

$p h z E$ and $p h z F$ fragments were amplified by PCR, with fragment sizes of $390 \mathrm{bp}$ and $399 \mathrm{bp}$, respectively. The nucleotide sequences of the $p h z E$ and $p h z F$ fragments from S. griseoruber Y1B were submitted to GenBank under accession numbers KF991393 and KF991394, respectively. The alignment of the $S$. griseoruber Y1B $p h z E$ and $p h z F$ fragments with those of phenazine-producing Pseudomonas and Streptomyces species showed 70-80\% similarity in both regions (Table 3). Among these phenazine-producing strains, S. anulatus 9663 and $S$. 
cinnamonensis DSM1042 can produce endophenazines (Seeger et al., 2011; Saleh et al., 2012), and P. chlororaphis GP72, P. aeruginosa M18, P. aeruginosa PAO1, and P. aeruginosa PA7 mainly produce simple carboxyl- and hydroxyl-substituted phenazine derivatives (Mavrodi et al., 2001; Huang et al., 2011; Li et al., 2011). These results indicated that $S$. griseoruber Y1B contained phenazine biosynthetic genes and may be able to produce phenazine compounds.

Table 3. Comparison of nucleotide similarity in the phenazine biosynthetic gene cluster between $S$. griseoruber Y1B and other phenazine-producing strains

\begin{tabular}{llll}
\hline \multirow{2}{*}{ Phenazine-producing strains } & \multirow{2}{*}{ Accession no. } & \multicolumn{2}{l}{ Gene similarity } \\
\cline { 3 - 4 } & & phzE & phzF \\
\hline Streptomyces anulatus 9663 & FN178498 & $79 \%$ & $72 \%$ \\
Streptomyces cinnamonensis DSM1042 & AM384985 & $80 \%$ & $72 \%$ \\
Pseudomonas chlororaphis GP72 & HM594285 & $76 \%$ & $70 \%$ \\
Pseudomonas aeruginosa M18 & CP002496 & $80 \%$ & $71 \%$ \\
Pseudomonas aeruginosa PAO1 & AE004091 & $80 \%$ & $71 \%$ \\
Pseudomonas aeruginosa PA7 & CP000744 & $80 \%$ & $72 \%$ \\
\hline
\end{tabular}

\subsection{Antifungal Activity Test In vitro}

The antifungal activity of $S$. griseoruber Y1B was characterized by its ability to inhibit the growth of four plant pathogens. As shown in Figure 2, the crude extract of $S$. griseoruber $\mathrm{Y} 1 \mathrm{~B}$, at $50 \mathrm{mg} \mathrm{l}^{-1}$, showed inhibitory effect against Rhizoctonia solani, Pythiumultimum, Fusarium oxysporum and Stevia rebaudiana Bertoni spot blight, with relative inhibition rates of $47.7 \%, 20.6 \%, 31.0 \%$ and $6.4 \%$, respectively. The results indicated that $S$. griseoruber Y1B exhibited different inhibition effect against different plant pathogens, and had a broad spectrum of antifungal activity. In addition, S. griseoluteus P510, which had been reported as another phenazine-producing Streptomyces species, with the concentration of crude extract at $70 \mathrm{mg}^{-1}$, showed relative inhibition rates of $22.2 \%$ and $11.1 \%$ against Rhizoctonia solani and Pythiumultimum, respectively (Wang et al., 2011). Therefore, as a novel Streptomyces strain, $S$. griseoruber Y1B might have potential applications for biocontrol in agricultural production. 
Blank control plate Solvent control plate

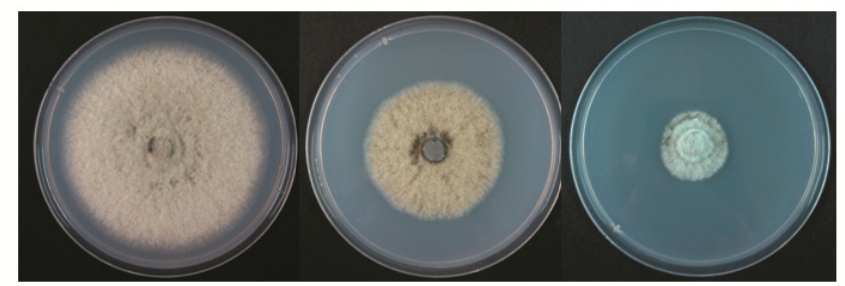

B

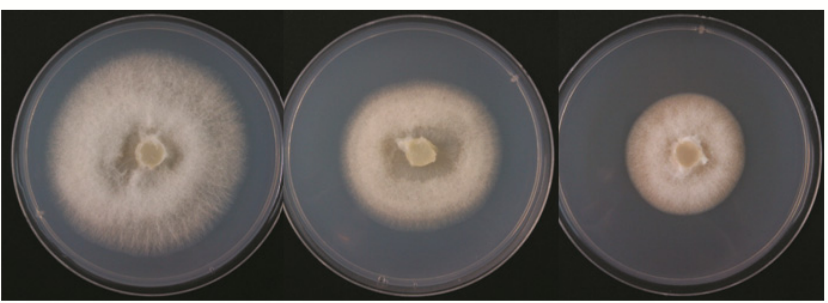

C

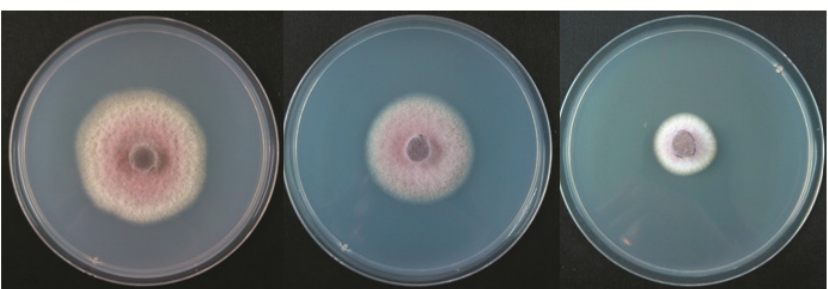

D

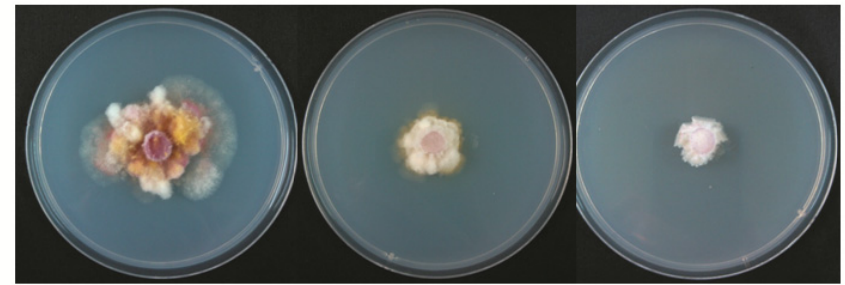

Relative inhibition rate (\%)

$47.7 \pm 4.3$

$20.6 \pm 3.0$

$31.0 \pm 2.3$

$6.4 \pm 0.6$

Figure 2. Inhibitory effect of the crude extract of S. griseoruber Y1B fermentation broth against different plant pathogens. (a) Rhizoctonia solani. (b) Pythiumultimum. (c) Fusarium oxysporum. (d) Stevia rebaudiana Bertoni spot blight. The data shown are the averages of triplicate experiments with standard deviations

\subsection{Structure Elucidation of the Active Compound}

The isolation scheme of compounds 1 and 2 is shown in Figure 3. The yield of dry crude extract from $25 \mathrm{~L}$ of fermentation broth was $2.6 \mathrm{~g}$, and compounds 1 (3.8 mg) and 2 (5.2 $\mathrm{mg})$ were collected from by preparative HPLC (Figures S1 and S2). 


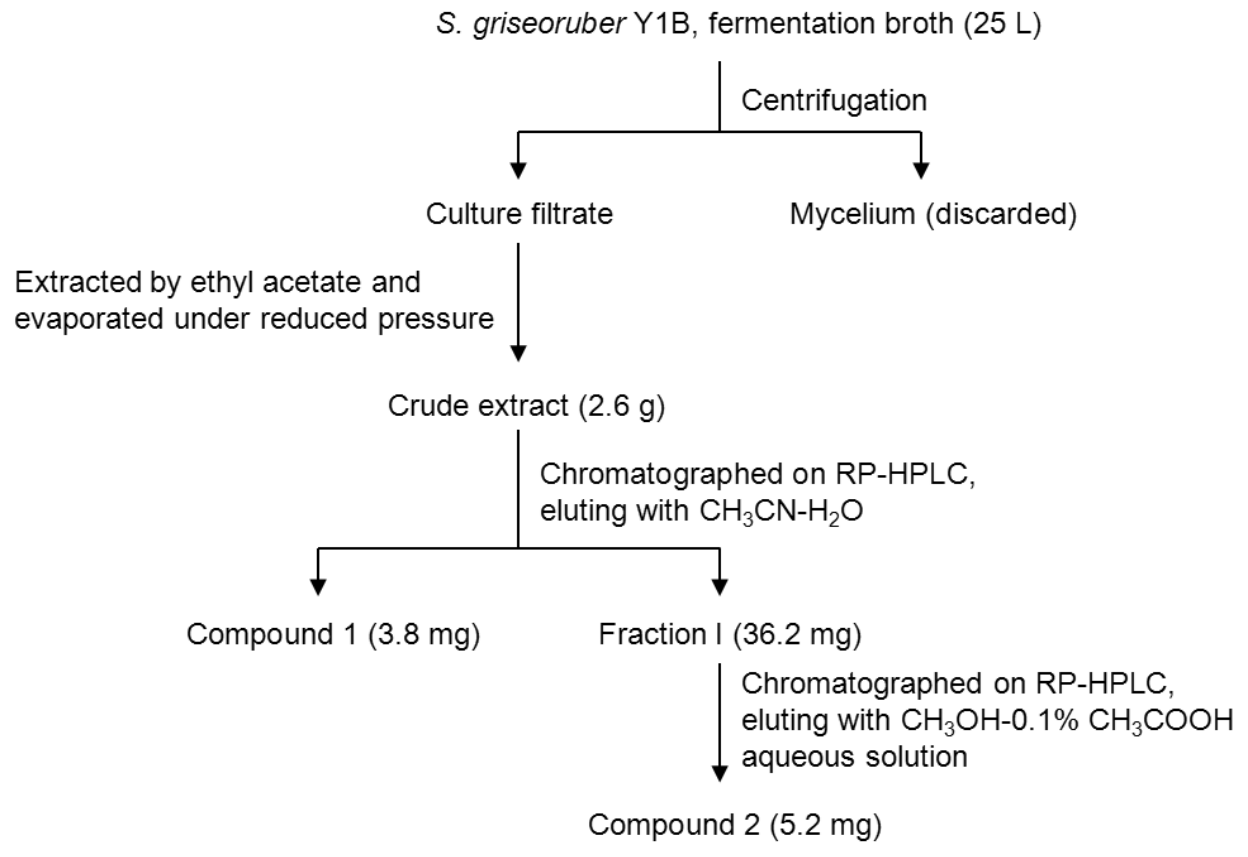

Figure 3. Separation and purification scheme of active compounds from S. griseoruber Y1B

Compound 1 was obtained as an orange, amorphous powder. High-resolution ESI-MS displayed a positive peak at m/z $197.0809[\mathrm{M}+\mathrm{H}]^{+}$, and three distinct peaks at $203 \mathrm{~nm}, 259$ $\mathrm{nm}$, and $367 \mathrm{~nm}$ were found in the UV absorption spectrum (Figure S3), indicating that compound 1 may have an aromatic ring structure. The ${ }^{1} \mathrm{H}$ NMR spectrum of compound 1 showed chemical shifts of $H$ protons at $\delta 7.19,7.69,7.79,7.91,8.18$, and 8.31 (Figure S4). Based on the comparison of the molecular mass, UV absorption spectrum, and ${ }^{1} \mathrm{H}$ NMR spectrum with published data (Mavrodi et al., 2001; Dharni, 2012), the structure of compound 1 was identified as 1-hydroxyphenazine (1-OH-PHZ, $\mathrm{C}_{12} \mathrm{H}_{8} \mathrm{~N}_{2} \mathrm{O}, \mathrm{MW}=196.20$ ).

Compound 2 was obtained as a white, needle-like crystal. High-resolution ESI-MS exhibited a negative peak at $\mathrm{m} / \mathrm{z} 121.0281[\mathrm{M}-\mathrm{H}]^{-}$, as shown in Figure S5, and the UPLC-MS-MS spectrum displayed a base peak at $\mathrm{m} / \mathrm{z} 77.0396$, which indicated the presence of a benzene ring $\left(\mathrm{C}_{6} \mathrm{H}_{6}\right)$. The ${ }^{1} \mathrm{H}$ NMR spectrum of compound 2 showed chemical shifts of $\mathrm{H}$ protons at $\delta$ 7.45, 7.58, and 8.01 (Figure S6). According to the molecular mass, UPLC-MS-MS, and ${ }^{1} \mathrm{H}$ NMR spectrum, the structure of compound 2 was identified as benzoic acid $\left(B A, \mathrm{C}_{7} \mathrm{H}_{6} \mathrm{O}_{2}\right.$, $\mathrm{MW}=122.12$ ).

$S$. griseoruber has previously been reported as a kind of antibiotic-producing strain in the medical field. For example, S. griseoruber MTCC8121_CKM5, S. griseoruber 4620, and S. griseoruber 1618-306 can produce actinomycin D, rhodomycin, and anthracyclinone, respectively, which have showed antitumor activity in the clinical application (Podojil et al., 1980; Přikrylová et al., 1980; Bakina et al., 1989; Praveen \& Tripathi, 2009). In this study, $S$. griseoruber $\mathrm{Y} 1 \mathrm{~B}$ was shown to produce 1-OH-PHZ, which is the first description of the production of a phenazine compound by $S$. griseoruber in the agricultural field. 
3.6 Effects of Intermediate Metabolites on Phenazine Compound Production
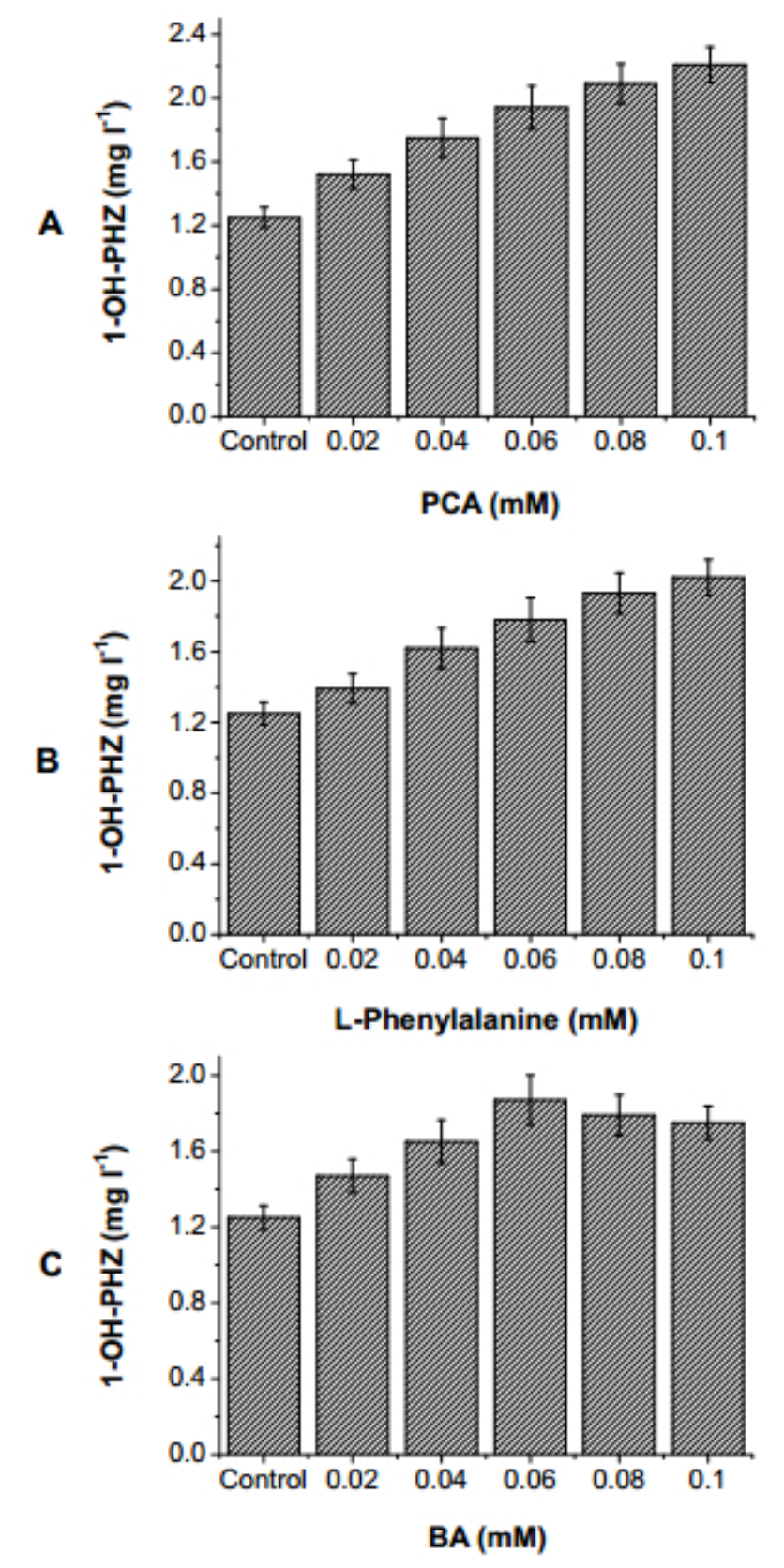

Figure 4. Production of 1-OH-PHZ with the addition of PCA (a), L-phenylalanine (b), and $\mathrm{BA}$ (c) in $250 \mathrm{ml}$ shake flasks containing $60 \mathrm{ml}$ of GYM medium. Results are averages of triplicate experiments and error bars indicate standard deviations of the means

The effects of intermediate metabolites on 1-OH-PHZ production are shown in Figure 4. The production of 1-OH-PHZ increased from $1.25 \mathrm{mg} \mathrm{l}^{-1}$ to $2.21 \mathrm{mg} \mathrm{l}^{-1}$ with the addition of 0.1 $\mathrm{mM}$ PCA. In the phenazine biosynthesis pathway, the biosynthesis of natural phenazine derivatives is the consequence of different modifications of a limited number of phenazine precursors, a biosynthesis mechanism that is conserved in all bacterial phenazine producers. These phenazine precursors might be PCA and phenazine-1,6-dicarboxylic acid (PDC), and 


\section{Macrothink}

the gene product of $p h z S$ is involved in the conversion of PCA into 1-OH-PHZ (Mentel et al., 2009; Pierson III \& Pierson, 2010). Therefore, the addition of PCA contributes to the production of 1-OH-PHZ.

In general, addition of L-phenylalanine and BA increased the production of 1-OH-PHZ to some extent. L-phenylalanine is an important intermediate metabolite in the shikimate pathway, and L-phenylalanine can be degraded into BA (Moerkercke et al., 2009). The addition of L-phenylalanine and BA might inhibit L-phenylalanine metabolism, and promote an increase of branched metabolic flux in the shikimate pathway, including the phenazine biosynthesis pathway. At the same time, BA itself could have a toxic effect on the microbial cells and inhibit the growth of $S$. griseoruber Y1B, which might lead to the decline in production of 1-OH-PHZ with the addition of BA at $0.08 \mathrm{mM}$ and $0.1 \mathrm{mM}$.

Consequently, it can be inferred that the phenazine biosynthesis pathway in $S$. griseoruber Y1B might branch off from the shikimate pathway, and that PCA and L-phenylalanine might be biosynthesized as the precursors of 1-OH-PHZ and BA, respectively. The proposed phenazine biosynthesis pathway in $S$. griseoruber Y1B is shown in Figure 5. 


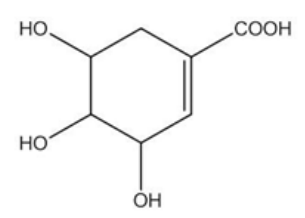

Shikimic acid<smiles>C=C(O[C@@H]1C=C(C(=O)O)C=C[C@H]1O)C(=O)O</smiles>

Chorismic acid
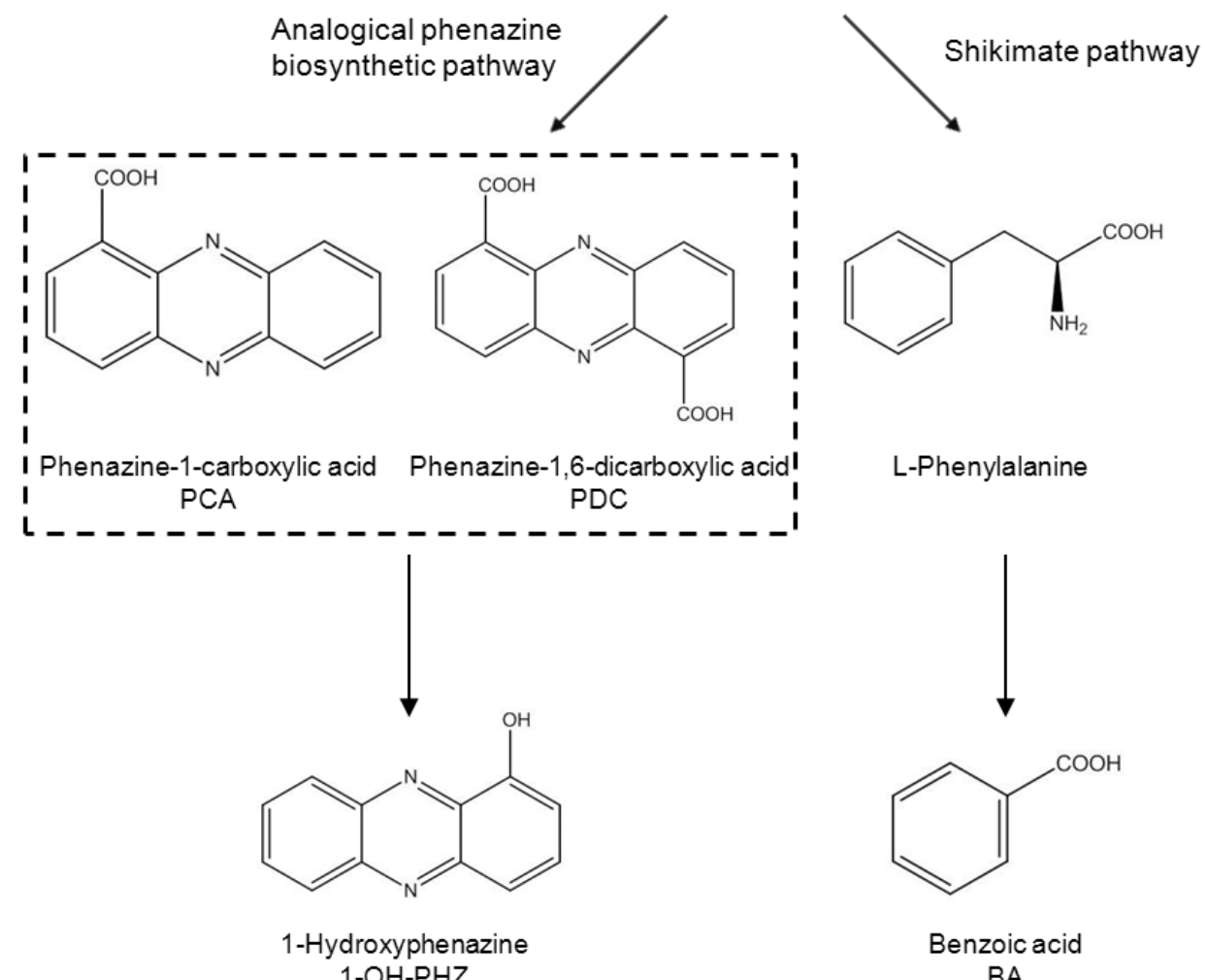<smiles>N[C@@H](Cc1ccccc1)C(=O)O</smiles>

L-Phenylalanine<smiles>CCCCCC(=O)O</smiles>

Benzoic acid BA

Figure 5. Schematic illustration of the proposed phenazine biosynthesis pathway in $S$. griseoruber Y1B

\section{Conclusion}

A novel phenazine-producing strain named Y1B was isolated from soil in this study. Based on phenotypic characteristics and 16S rRNA gene sequence analysis, strain Y1B was identified as $S$. griseoruber. In addition, we analyzed the fatty acid composition of $S$. 
griseoruber Y1B to provide the first fatty acid profiles of a $S$. griseoruber strain. phzE and $p h z F$ were selected as phenazine biosynthetic gene markers to detect the phenazine-producing potential of $S$. griseoruber Y1B. phzE and $p h z F$ gene fragments were amplified by PCR, and showed $70-80 \%$ similarity to those of phenazine-producing Pseudomonas and Streptomyces species. The crude extract obtained from S. griseoruber Y1B fermentation broth showed significant activity against Rhizoctonia solani, Pythiumultimum and Fusarium oxysporum, with relative inhibition rates of $47.7 \%, 20.6 \%$ and $31.0 \%$, respectively. These results indicated that $S$. griseoruber Y1B contained phenazine biosynthetic genes and has a broad spectrum of antifungal activity.

S. griseoruber Y1B could produce 1-OH-PHZ and BA, and might use PCA as the phenazine precursor to biosynthesize phenazine compounds, which is the first description of the production of a phenazine compound by $S$. griseoruber. The discovery of $S$. griseoruber Y1B offers a new source for the isolation of phenazine-producing strains in the agricultural field. As a new Streptomyces strain, S. griseoruber Y1B may play an important role in biocontrol in the future.

\section{Acknowledgments}

Financial supports from the 863 Programs of China (Grant No. 2012AA022107) and the National Natural Science Foundation of China (NSFC project No. 20706037) are gratefully acknowledged.

\section{References}

Bakina, E., Iartseva, I., Povarov, L., Aleksandrova, L., Tulemisova, K., Mamonova, L., \& Preobrazhenskaia, M. (1989). Establishing the structure of anthracyclinones produced by Streptomyces griseoruber. Bioorg. Khim, 15(10), 1423-1430.

Brosius, J., Palmer, M. L., Kennedy, P. J., \& Noller, H. F. (1978). Complete nucleotide sequence of a 16S ribosomal RNA gene from Escherichia coli. Proc. Natl. Acad. Sci., 75(10), 4801-4805. http://dx.doi.org/10.1073/pnas.75.10.4801

Dharni, S. (2012). Production, purification, and characterization of antifungal metabolite from Pseudomonas aeruginosa SD12, a new strain obtained from tannery waste polluted soil. J. Microbiol. Biotechnol., 22(5), 674-683. http://dx.doi.org/10.4014/jmb.1109.09061

Eerola, E., \& Lehtonen, O. P. (1988). Optimal data processing procedure for automatic bacterial identification by gas-liquid chromatography of cellular fatty acids. J. Clin. Microbiol., 26(9), 1745-1753.

Gorgolous, S., \& Dekker, J. (1982). Detection and measurement of fungicide resistance general principles. FAO. Pl. Prot. Bull., 30(2), 39-71.

Huang, L., Chen, M., Wang, W., Hu, H., Peng, H., Xu, Y., \& Zhang, X. (2011). Enhanced production of 2-hydroxyphenazine in Pseudomonas chlororaphis GP72. Appl. Microbiol. Biotechnol., 89(1), 169-177. http://dx.doi.org/10.1007/s00253-010-2863-1

Krastel, P., Zeeck, A., Gebhardt, K., Fiedler, H. P., \& Rheinheimer, J. (2002). Endophenazines 
A-D, new phenazine antibiotics from the arthropod associated endosymbiont Streptomyces anulatus II. Structure elucidation. J. Antibiot., 55(9), 801-806. http://dx.doi.org/10.7164/antibiotics.55.801

Kroppenstedt, R., Stackebrandt, E. M., \& Goodfellow, M. (1990). Taxonomic revision of the actinomycete genera Actinomudura and Microtetruspora. Syst. Appl. Microbiol., 13, 148-160. http://dx.doi.org/10.1016/S0723-2020(11)80162-1

Laursen, J. B., \& Nielsen, J. (2004). Phenazine natural products: biosynthesis, synthetic analogues, and biological activity. Chem. Rev., 104(3), 1663-1686. http://dx.doi.org/10.1021/cr020473j

Li, Y., Du, X., Lu, Z., Wu, D., Zhao, Y., Ren, B., Huang, J., Huang, X., \& Xu, Y. (2011). Regulatory feedback loop of two phz gene clusters through $5^{\prime}$-untranslated regions in $\begin{array}{lllll}\text { Pseudomonas } & \text { sp. } & \text { M18. } & \text { PLOS } & \text { 6(4), }\end{array}$ http://dx.doi.org/10.1371/journal.pone.0019413

Ligon, J. M., Hill, D. S., Hammer, P. E., Torkewitz, N. R., Hofmann, D., Kempf, H. J., \& Pée, K. H. (2000). Natural products with antifungal activity from Pseudomonas biocontrol bacteria. Pest. Manag. Sci., 568 http://dx.doi.org/10.1002/1526-4998(200008)56:8\%3C688::AID-PS186\%3E3.3.CO;2-M

Mavrodi, D. V., Bonsall, R. F., Delaney, S. M., Soule, M. J., Phillips, G., \& Thomashow, L. S. (2001). Functional analysis of genes for biosynthesis of pyocyanin and phenazine-1-carboxamide from Pseudomonas aeruginosa PAO1. J. Bacteriol., 183(21), 6454-6465. http://dx.doi.org/10.1128/JB.183.21.6454-6465.2001

McDonald, M., Mavrodi, D. V., Thomashow, L. S., \& Floss, H. G. (2001). Phenazine biosynthesis in Pseudomonas fluorescens: branchpoint from the primary shikimate biosynthetic pathway and role of phenazine-1, 6-dicarboxylic acid. J. Am. Chem. Soc., 123(38), 9459-9460. http://dx.doi.org/10.1021/ja011243+

Mentel, M., Ahuja, E. G., Mavrodi, D. V., Breinbauer, R., Thomashow, L. S., \& Blankenfeldt, W. (2009). Of two make one: the biosynthesis of phenazines. Chem. Bio. Chem., 10(14), 2295-2304. http://dx.doi.org/10.1002/cbic.200900323

Moerkercke, A. V., Schauvinhold, I., Pichersky, E., Haring, M. A., \& Schuurink, R. C. (2009). A plant thiolase involved in benzoic acid biosynthesis and volatile benzenoid production. Plant. J., 60(2), 292-302. http://dx.doi.org/10.1111/j.1365-313X.2009.03953.x

Pierson III, L. S., \& Pierson, E. A. (2010). Metabolism and function of phenazines in bacteria: impacts on the behavior of bacteria in the environment and biotechnological processes. Appl. Microbiol. Biotechnol., 86(6), 1659-1670. http://dx.doi.org/10.1007/s00253-010-2509-3

Podojil, M., Blumauerová, M., Přikrylová, V., Vaněk, Z., Gauze, G., \& Maksimova, T. (1980). Production of rhodomycins in Streptomyces griseoruber 4620. Folia. Microbiol., 25(6), 464-466. http://dx.doi.org/10.1007/BF02897211

Praveen, V., \& Tripathi, C. (2009). Studies on the production of actinomycin-D by 
Streptomyces griseoruber-a novel source. Lett. Appl. Microbiol., 49(4), 450-455. http://dx.doi.org/10.1111/j.1472-765X.2009.02689.x

Přikrylová, V., Podojil, M., Sedmera, P., Vokoun, J., Vaněk, Z., Brazhnikova, M. G., \& Kudinova, M. K. (1980). New rhodomycinone from the strain Streptomyces griseoruber 4620. Collect. Czech. Chem. Commun., 45(7), 1991-1995. http://dx.doi.org/10.1135/cccc19801991

Saitou, N., \& Nei, M. (1987). The neighbor-joining method: a new method for reconstructing phylogenetic trees. Mol. Biol. Evol., 4(4), 406-425.

Saleh, O., Flinspach, K., Westrich, L., Kulik, A., Gust, B., Fiedler, H. P., \& Heide, L. (2012). Mutational analysis of a phenazine biosynthetic gene cluster in Streptomyces anulatus 9663. Beilstein. J. Org. Chem., 8, 501-513. http://dx.doi.org/10.3762/bjoc.8.57

Schneemann, I., Wiese, J., Kunz, A. L., \& Imhoff, J. F. (2011). Genetic approach for the fast discovery of phenazine producing bacteria. Mar. Drugs., 9(12), 772-789. http://dx.doi.org/10.3390/md9050772

Seeger, K., Flinspach, K., Haug-Schifferdecker, E., Kulik, A., Gust, B., Fiedler, H. P., \& Heide, L. (2011). The biosynthetic genes for prenylated phenazines are located at two different chromosomal loci of Streptomyces cinnamonensis DSM 1042. Microb. Biotechnol., $4(2), 252-262$. http://dx.doi.org/10.1111/j.1751-7915.2010.00234.x

Shirzad, A., Fallahzadeh-Mamaghani, V., \& Pazhouhandeh, M. (2012). Antagonistic potential of fluorescent pseudomonads and control of crown and root rot of cucumber caused by Phytophthora drechsleri. Plant. Pathol. J., $\quad 28(1), \quad$ 1-9. http://dx.doi.org/10.5423/PPJ.OA.05.2011.0100

Tamura, K., Dudley, J., Nei, M., \& Kumar, S. (2007). MEGA4: molecular evolutionary genetics analysis (MEGA) software version 4.0. Mol. Biol. Evol., 24(8), 1596-1599. http://dx.doi.org/10.1093/molbev/msm092

Tatusova, T. A., \& Madden, T. L. (1999). BLAST 2 sequences, a new tool for comparing protein and nucleotide sequences. FEMS. Microbiol. Lett., 174(2), 247-250. http://dx.doi.org/10.1111/j.1574-6968.1999.tb13575.x

Wang, Y., Luo, Q., Zhang, X., \& Wang, W. (2011). Isolation and purification of a modified phenazine, griseoluteic acid, produced by Streptomyces griseoluteus P510. Res. Microbiol., 162(3), 311-319. http://dx.doi.org/10.1016/j.resmic.2011.01.005

\section{Copyright Disclaimer}

Copyright reserved by the author(s).

This article is an open-access article distributed under the terms and conditions of the Creative Commons Attribution license (http://creativecommons.org/licenses/by/3.0/). 


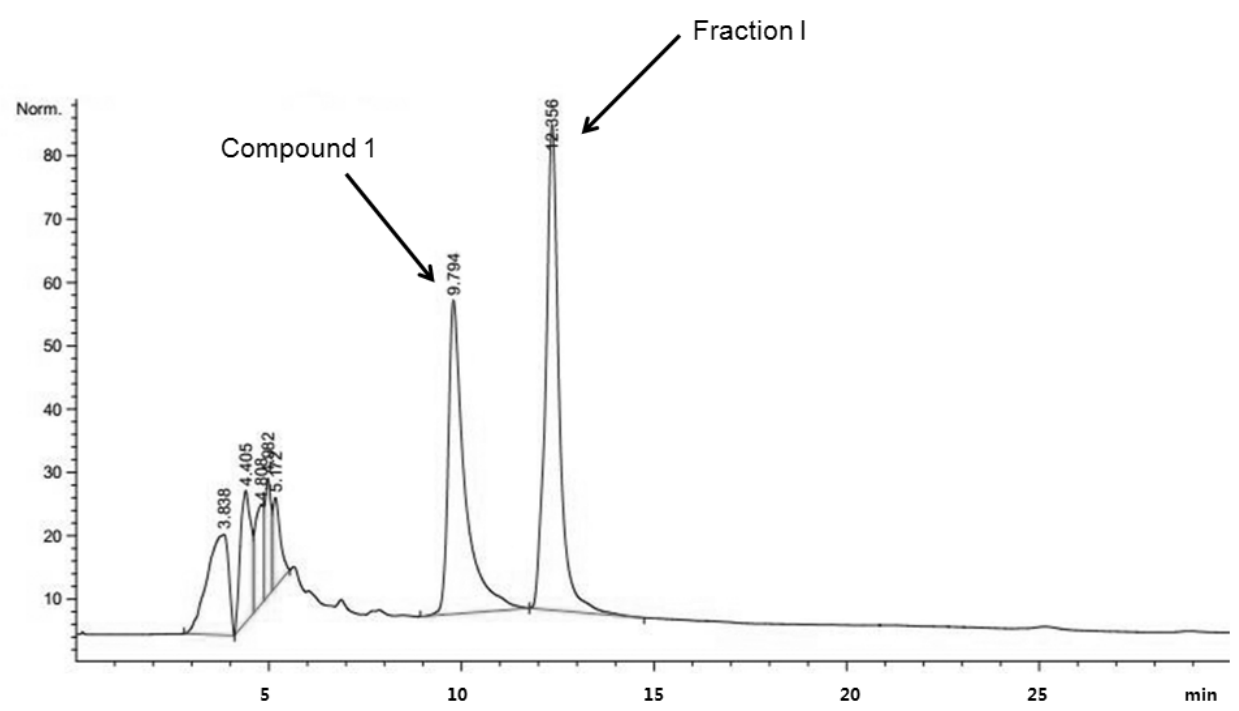

Figure S1. HPLC analysis of dry crude extract from S. griseoruber Y1B fermentation broth. Detection wavelength: $254 \mathrm{~nm}$

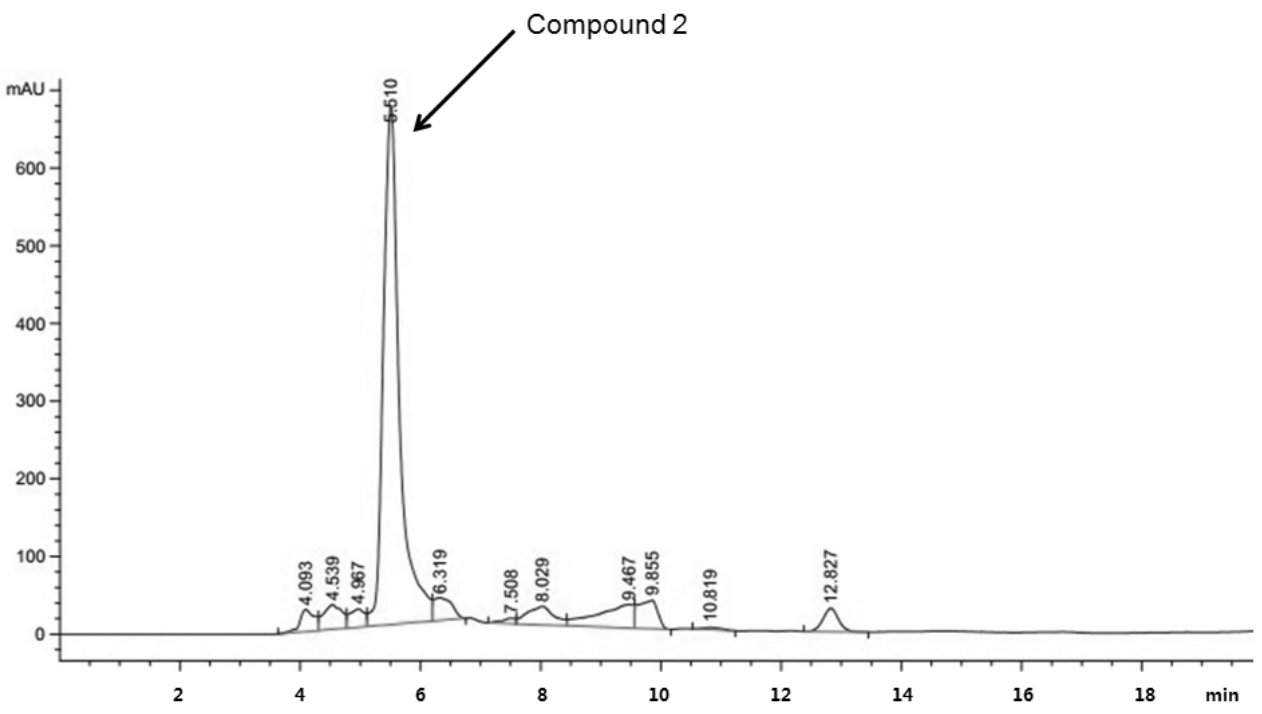

Figure S2. HPLC analysis of fraction I. Detection wavelength: $254 \mathrm{~nm}$ 
A

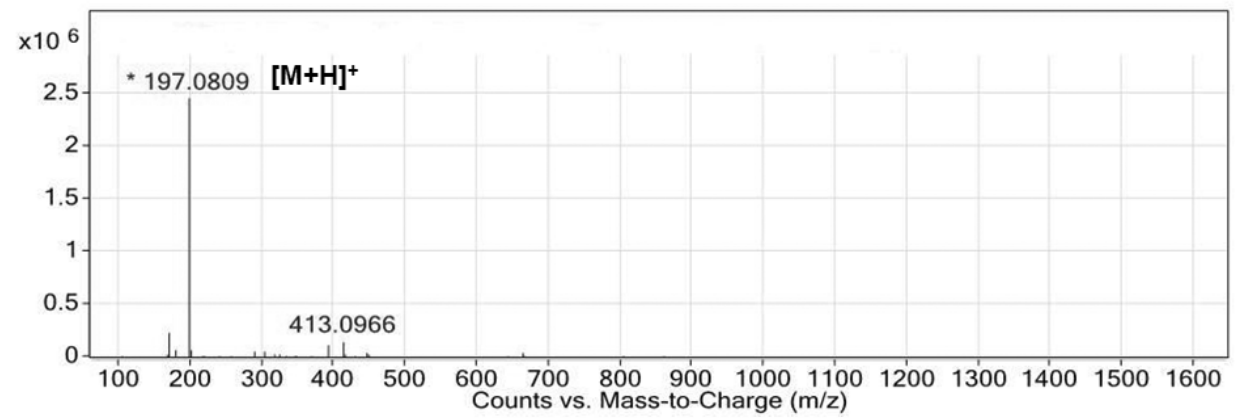

B

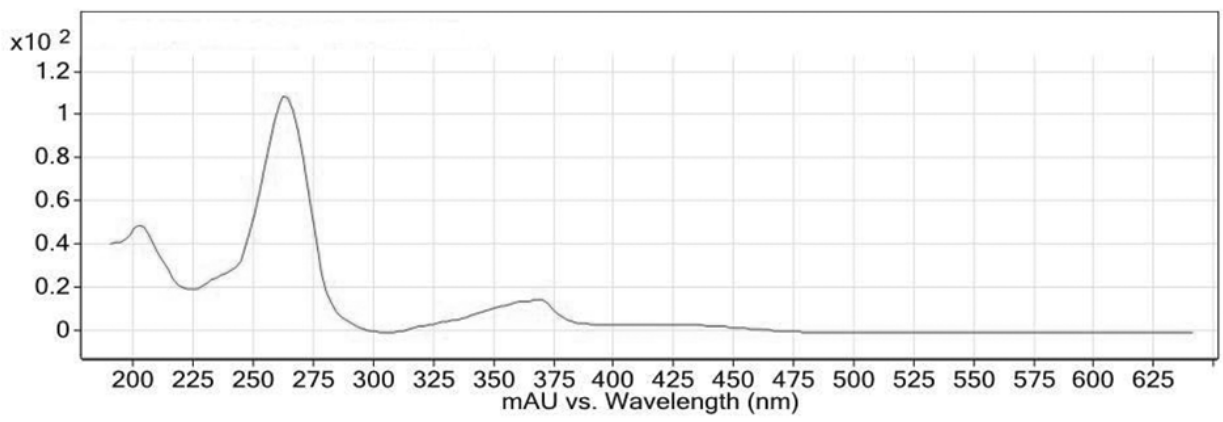

Figure S3. ESI-MS spectrum (a) and UV absorption spectrum (b) of compound 1
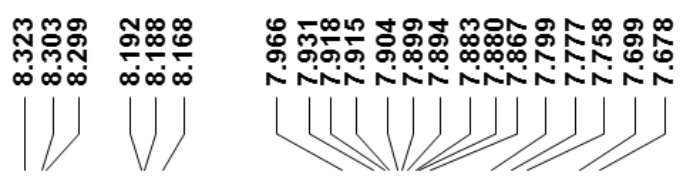

옫․․

$\mathrm{C}-6,8$

$7.91, \mathrm{~m}$

C-4

$7.69, \mathrm{dd}$

\section{C-7}

C-9 8.18, dd

8.31, dd

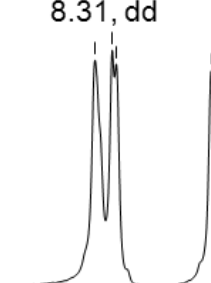

i
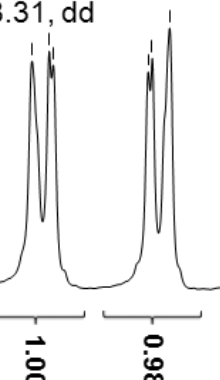

iे

$\mathrm{C}-3$

$7.78, \mathrm{dd}$

$\mathrm{OH}$

C-2

7.19, dd<smiles>Cc1cccc2nc3ccccc3nc12</smiles>

1-Hydroxyphenazine (1-OH-PHZ)
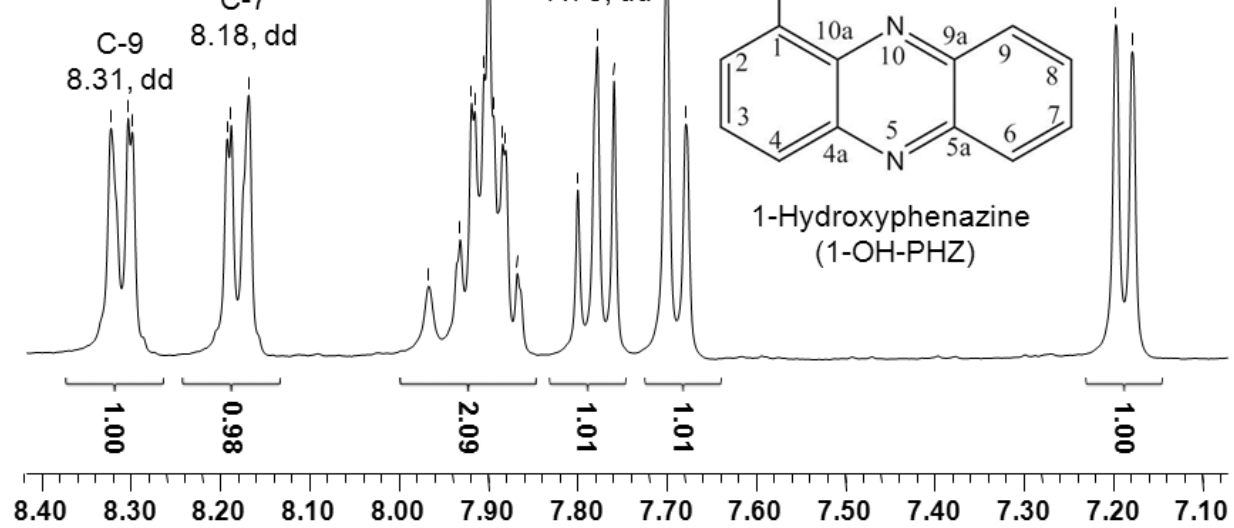

Figure S4. ${ }^{1} \mathrm{H}$ NMR data of compound 1 in $\mathrm{CD}_{3} \mathrm{OD}$ 
A

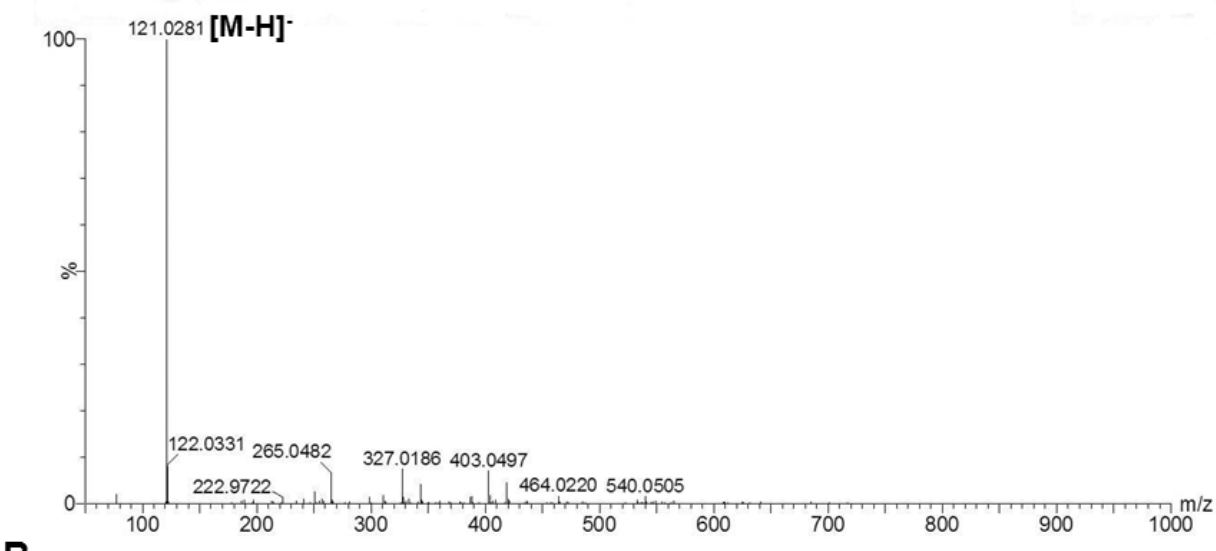

B

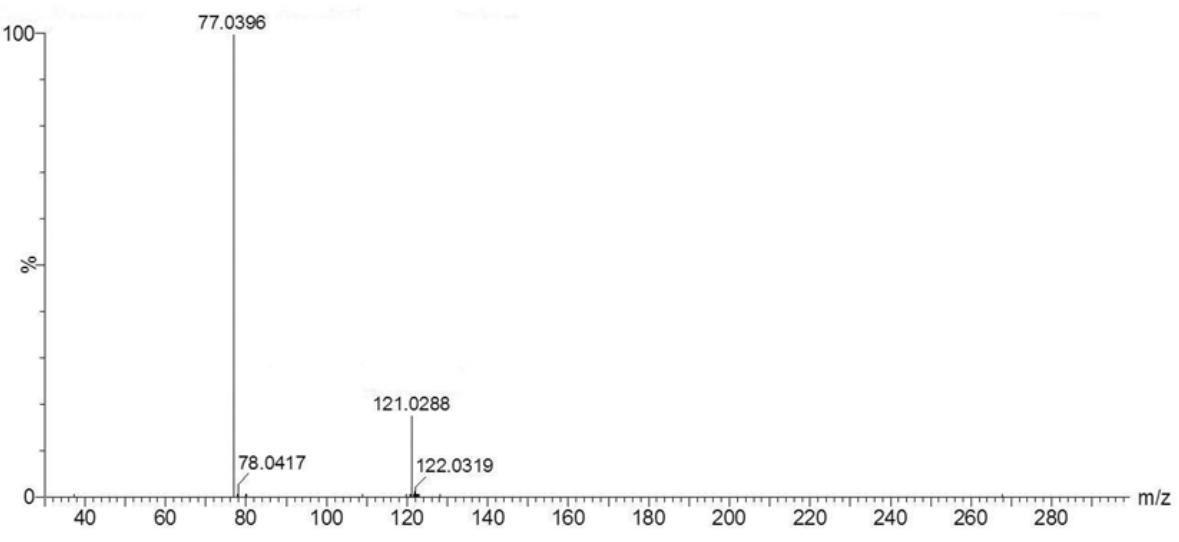

Figure S5. ESI-MS spectrum (a) and UPLC-MS-MS spectrum (b) of compound 2

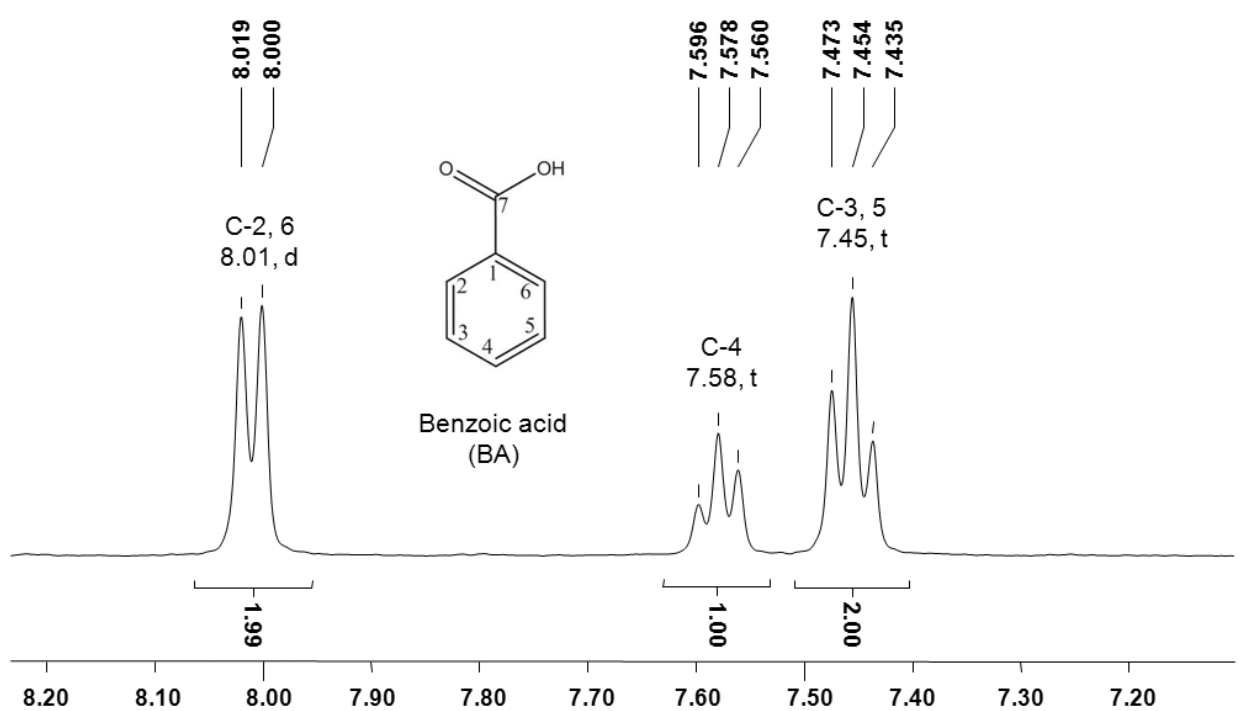

Figure S6. ${ }^{1} \mathrm{H}$ NMR data of compound 2 in $\mathrm{CD}_{3} \mathrm{OD}$ 